\title{
PERKEMBANGAN DAN EKSISTENSI HUKUM PIDANA ISLAM SEBAGAI SUMBER HUKUM DI INDONESIA
}

\author{
Syarif Hidayatullah \\ Institut Agama Islam (IAI) Muhammadiyah Bima \\ Jl. Anggrek No. 16 Ranggo Na'e Kota Bima \\ ink.syarif@gmail.com
}

\begin{abstract}
:
The Islamic Law not only the low which realize in religious context, but also it become the resource law in constitution partly or generally. In civil law it is still particularly and generally, meanwhile in criminal law it does not concern seriously. Although, there are many problems which need to solve with the new innovative low especially in criminal, so the resource of law must be already to create peace and good manners. In this paper, writer use the juridical historical approach, which study about how propagation of Islamic Law as the resource of criminal law (jinayah), and how it gives idea and concept which make criminal law in Indonesia more propagate. Finally, it so helpful to criminal law in Indonesia.
\end{abstract}

Keywords: Law, Islam, Criminal.

\section{Pendahuluan}

Hukum pidana Islam atau Islamic criminal law menurut asas legalitasnya dikategorikan sebagai hukum yang tidak tertulis. Namun demikian, sebenarnya hukum pidana Islam dapat diakui secara konstitusional sebagai hukum yang terus berlaku. Hukum Islam masih sering dipersepsikan kurang baik di kalangan ahli hukum, birokrat, dan elit politik, sehingga berpengaruh besar terhadap persepsi masyarakat. Dalam literatur fikih, hukum pidana lebih dikenal dengan sebutan alahkam al-jina'iyyah, yaitu hukum-hukum yang mengatur ucapan, sikap, atau perbuatan orang-orang mukallaf yang berkenaan dengan berbagai tindak pelanggaran atau kejahatan (jarimah/jinayah) berdasarkan jenisjenis ancaman hukuman yang patut diberikan.

Hukum pidana yang diberlakukan sekarang nampaknya belum dapat membuat para pelaku tindak kriminal jera dan takut, tetapi sebaliknya malah memberi peluang untuk melakukannya dengan cara dan trik 
yang lebih rapi guna dapat terhindar dari jeratan hukum pidana yang ada, dan kalaupun sampai dipidana, para pelaku kejahatan terkadang tidak mendapatkan sanksi hukum yang berat sehingga timbul anggapan bahwa hukum terasa pilih kasih. ${ }^{1} \mathrm{Hal}$ ini menjadi sebuah ironis yang cukup memusingkan, karena tidak adanya efektifitas dalam hukum pidana untuk menekan dari perilaku kejahatan, terlepas dari tujuan dan maksud, juga alasan-alasan pelaku kejahatan dalam melakukan kejahatannya tersebut.

Apakah perlu hukum Islam, menjadi alat pembantu dalam pembentukan hukum pidana di Indonesia?, tentu hal ini tidak serta-merta dapat diterima begitu saja oleh masyarakat, baik ada yang beralasan, di dalam hukum Islam terlebih dalam hukum pidana tidak sesuai dengan hak asasi manusia, ada juga dapat terjadi kecemburuan sosial antara umat beragama, hal-hal semacam ini tentu juga menjadi pertimbangan yang penting dalam proses legitimasi sebuah hukum pidana, karena sudah masuk dalam ranah Negara yang bersifat netral dan berlaku pagi seluruh rakyat.

Proses formalisasi syariat Islam dalam beberapa perspektif tata hukum Indonesia ternyata sangat dirasa rumit, karena berkaitan dengan berbagai aspek historis, ideologis, politis, yuridis, religius, sosiologis, dan kultural, baik di lingkup nasional maupun internasional. Aspek-aspek tersebut dalam realitasnya ternyata tidak berdiri sendiri, melainkan saling mempengaruhi satu dengan yang lainnya. Oleh sebab itu, proses formalisasi syariat Islam dalam tata hukum di Indonesia memerlukan waktu yang sangat panjang, melintasi beberapa periode dan generasi serta memunculkan problematika yang amat krusial. Jelasnya, melalui formalisasi dan legislasi, hukum Islam telah bergeser dari otoritas hukum agama (devin law) menjadi otoritas hukum negara (state law). ${ }^{2}$

${ }^{1}$ Marzuki, "Prospek Pemberlakuan Hukum Pidana Islam Di Indonesia" Universitas Yogyakarta,4.http:/ / staff.uny.ac.id/sites/default/files/penelitian/Dr. \% 20 Marzuki,\%20M.Ag./Dr.\%20Marzuki, \%20M.Ag_.\%20Prospek\%20Pemberlakuan \%20 Hukum\%20Pidana\%20Islam\%20di\%20Indonesia.pdf. (diakses tanggal 23 Oktober 2015).

2 Faisal, "Menimbang Wacana Formalisasi Hukum Pidana Islam di Indonesia" Ahkam: Vol. XII No.1 (2012), 44. http://download.portalgaruda.org/article. php? article $=176035 \& v a l=328 \&$ title $=$ Menimbang $\% 20$ Wacana $\% 20$ Formalisasi $\% 20$ Hukum\%20Pidana\%20Islam\%20di\%20Indonesia. (diakses tanggal 23 Oktober 2015).

Sangaji Jurnal Pemikiran Syariah dan Hukum 
Dari hal tersebut, perlu dilakukan inovasi baru yang lebih kongkrit dalam menyelesaikan kebuntuan hukum yang terjadi, dari hal itu hukum Islam tampil sebagai sumber hukum yang memberikan solusi, mengingat Islam secara hukum komplek salah satunya mengenai hukum pidana (jinayah), apalagi Islam hidup dan mengakar di masyarakat. Dari tulisan ini, penulis dengan mengunakan pendekatan yuridis-historis mencoba melihat bagaimana kedudukan hukum Islam serta eksistensinya di mata hukum sebagai sumber hukum yang mana mencoba memberikan sumbangsih dan pertimbangan dalam menciptakan produk hukum baru yang berkaitan mengenai hukum pidana, yang dianggap masih belum dapat menekan dan terjadi kekosongan hukum yang perlu diatur. Terlebih ada persoalan yang ada di masyarakat tetapi tidak diatur hukum namun ada dalam hukum Islam, mengingat hukum Islam hidup dan mengakar erat di masyarakat secara umum, terutama yang beragama Islam.

\section{Perkembangan Hukum Islam Di Indonesia}

Proses perkembangan hukum di Indonesia memiliki sejarah yang panjang dan perdebatan yang mendalam, karena memang hukum Islam yang menjadi pokok hukum dalam pembentukan hukum di Indonesia, terlebih hukum Islam bukan hanya menjadi sebuah hukum yang melekat dalam masyarakat tetapi juga menjadi pedoman dalam melakukan segala aktifitas, juga memiliki keragaman dan perspektif berbeda-beda dalam hukumnya terkait hal-hal yang dikaji.

Pemberlakuan hukum Islam di Indonesia agak tersendat dengan berkuasanya pemerintahan kolonial Belanda di Indonesia. Pemerintah Belanda berusaha menekan umat Islam dengan menghambat pemberlakuan hukum Islam secara resmi dengan dibuatnya aturanaturan yang sangat merugikan umat Islam. Dinamika pemberlakuan hukum Islam di Indonesia digambarkan dengan munculnya berbagai teori yang dikemukakan oleh para ahli (sejarawan), seperti teori penerimaan autoritas hukum dari H.A.R. Gibb, teori receptio in complex dari L.W.C. van den Berg, teori receptie dari C. Snouck Hurgronje yang kemudian dikembangkan oleh C. van Vollenhoven dan Ter Haar, teori 
receptie exit dari Hazairin, dan teori receptio a contrario dari Sajuti Thalib. ${ }^{3}$

Pada dasarnya Indonesia ada bermacam-macam hukum, baik itu hukum adat yang bersifat non-tertulis dan pemberlakuannya di setiap suatu daerah tertentu dengan karakterisitiknya masing-masing, selain itu hukum tersebut, yakni Hukum Agama, yang bukan hanya berlaku bersifat religius namun juga bersifat sosial, salah satunya adalah hukum Islam. Sejalan dengan perkembangan zaman dan kompleksitas permasalahan, kesadaran hukum masyarakat juga mengalami perkembangan. Salah satu wujudnya adalah bisa terjadi pengaruh-mempengaruhi antara suatu aliran atau mazhab dalam hukum Islam. Selain itu terjadinya persaingan dan bahkan konflik antara hukum Islam dan hukum adat serta antara hukum Islam dan hukum Barat, salah satu penyebabnya adalah campur tangan penjajah, baik Belanda maupun Jepang samasama mengeksploitasi Islam untuk kepentingan mereka. Akan tetapi Belanda hanya menyisakan peluang sangat kecil bagi kegiatan politik Islam, hal ini wajar karena kolonialisme dan imperialisme barat yang kejam itu pada mulanya berkaitan erat dengan proses perluasan agama mereka ke dalam masyarakat-masyarakat terjajah. Sedangkan Jepang membuka pintu bagi umat Islam untuk berpengalaman serta turut andil dalam politik dan bahkan latihan militer. ${ }^{4}$

Dalam realitasnya hukum pidana Islam diasumsikan sebagai hukuman kejam, sadis, dan tidak manusiawi. Setiap mendengar hukum pidana Islam, yang tersirat dalam benak orang yang tidak setuju tidak lebih dari sekadar hukum potong tangan, hukum rajam, dan qisas yang dikategorikan sebagai vonis. Asumsi-asumsi yang diungkapkan itu lebih sering berlatar belakang politis, bukan metodologis-juridis. Untuk itu, hukum pidana Islam perlu dipandang dalam kajian yang objektif dan bermuara pada pendekatan hukum. ${ }^{5}$

Lahirnya Undang-undang No 1 Tahun 1974 tentang Perkawinan menjadi langkah awal dalam proses legislasi hukum Islam walau dalam hal ini masih di batasi pada proses hukum keluarga, kewarisan.

${ }^{3}$ Marzuki, Prospek Pemberlakuan Hukum..., 1-2.

${ }^{4}$ Jazuni, Legislasi Hukum Islam di Indonesia (Bandung: Citra Aditya Bakti, 2005), 242-243.

5 Sahid HM, "Tinjauan Syari'ah Terhadap Hukum Pidana Mati”, Al-Daulah: Jurnal Hukum dan Perundangan Islam Vol. 2 No. 1 (2012), 49-50. http://aldaulah.uinsby.ac.id/index.php/ aldaulah/article/download/116/103. (diakses tanggal 8 Desember 2015).

Sangaji Jurnal Pemikiran Syariah dan Hukum 
Meskipun tidak bersifat keseluruhan, akan tetapi asas serta konsep dalam perkawinan menjadi penting terutama bagi Warga negara yang berstatus agama Islam. Kemudian lahirnya Undang-undang tentang Pengadilan Agama No. 7 tahun 1989, Undang-undang tentang penyelenggaraan Ibadah Haji, Undang-undang Pengelolaan Zakat, Kompilasi Hukum Islam, Undang-undang Otonomi Khusus Aceh serta Undang-undang tentang Perbankan Syariah. Semua itu, merupakan reformasi hukum yang dari konsep fikih ke ranah Hukum Negara dan menjadi bentuk dari karakteristik hukum Islam yang berlaku di Indonesia.

\section{Hukum Pidana Dalam Konsep Islam}

Dalam hukum Islam hukum pidana disebut dengan fiqh jināyah. Jināyah berarti "perbuatan yang dilarang oleh syara' baik perbuatan tersebut mengenai jiwa, harta maupun lainnya". Pengertian lain yang lebih operasional adalah "segala ketentuan hukum mengenai tindakan pidana atau perbuatan kriminal yang dilakukan mukallaf (orang yang dapat dibebani kewajiban), sebagai hasil dari pemahaman atas dalil-dalil hukum yang terperinci dari al-Qur'an dan hadis Nabi Muhammad Saw. ${ }^{6}$

Dari pengertian di atas dapat dipahami bahwa figh jināyah adalah ilmu yang membicarakan tentang jenis-jenis hukum yang diperintahkan dan dilarang al-Qur'an dan hadis Nabi Saw, serta hukuman yang akan dikenakan kepada orang yang melanggar baik perintah maupun larangan tersebut (tindakan kriminal) yang dimaksud tindakan kriminal adalah perbuatan kejahatan yang menggunakan ketertiban umum serta tindakan melawan peraturan perundang-undangan.

Dalam hukum pidana Islam, terdapat beberapa asas yang terkandung di dalamnya, antara lain: ${ }^{7}$

1. Asas keadilan;

2. Asas manfaat;

3. Asas keseimbangan;

4. Asas kepastian hukum;

${ }^{6}$ Asep Saepudin Jahar dan Euis Nurlaelawati-Jaenal Aripin, Hukum Keluarga, Pidana \& Bisnis Kajian Perudang-undangan Indonesia, Fikih dan Hukum Internasional (Jakarta: Kencana, 2013), 111.

${ }^{7}$ Neng Djubaedah, Perzinaan Dalam Peraturan Perundang-undangan di Indonesia Ditinjau Dari Hukum Islam (Jakarta: Kencana, 2010), 14. 
5. Asas dilarang memindahkan kesalahan kepada orang lain;

6. Asas praduga tak bersalah;

7. Asas legalitas;

8. Asas tidak berlaku surut (non-retriaktif);

9. Asas pemberian maaf;

10. Asas taubat;

11. Asas musyawarah;

12. Asas kondisional;

13. Asas ekualitas;

14. Asas perlindungan terhadap korban;

15. Sahnya hukuman karena keraguan; ${ }^{8}$

16. Prinsip kesamaan di hadapan hukum. ${ }^{9}$

Dalam pandangan al-Syâthibî, hukum Islam, termasuk juga hukum pidananya, ditempatkan untuk melindungi lima hak dasar/asasi manusia (al-dharûriyyât al-khams), yang meliputi perlindungan terhadap jiwa (hifzh al-nafs), perlindungan terhadap akal (hifzh al-'aql),perlindungan terhadap agama (hifzh al-dîn), perlindungan terhadap harta (hifzh al-mâl), dan perlindungan terhadap keturunan (hifzh al-nasl). ${ }^{10}$

Dalam usaha mewujudkan dan memelihara lima unsur pokok itu al-Syathibi mengemukakan tiga peringkat maqashid al-syari'ah(tujuan syariat), yaitu pertama adalah tujuan primer (maqashid al-daruriyyah), kedua adalah tujuan sekunder (maqashid al-hajjiyyah), dan ketiga tujuan tertier (maqashid al-tahsiniyyah). Atas dasar inilah maka hukum Islam dikembangkan, baik hukum pidana, perdata, ketatanegaraan, politik hukum, maupun yang lainnya. ${ }^{11}$ Dari konsep itu terlihat al-Syathibi membentuk dasar yakni kelima unsur pokok tersebut dan membagi tiga keberlakuan dari kelima pokok poin sehingga memberikan pemahaman bagaimana hukum yang tepat dan sanksi yang sesuai dengan pokok mana yang dikategorikan seorang tersebut melanggar.

Pada umumnya para ulama membagi figh jināyah (hukum pidana Islam) pada dua bagian besar, yakni: jenis perbuatan pidana (jarimah)

${ }^{8}$ Topo Santoso, Membumikan Hukum Pidana Islam: Penegakan Syariat dalam Wacana dan Agenda (Jakarta: Gema Insani Press, 2003), 15.

${ }^{9}$ Ibid., 17

${ }^{10}$ Faisal , "Menimbang Wacana Formalisasi..., 37.

${ }^{11}$ Marzuki, Prospek Pemberlakuan Hukum..., 7.

Sangaji Jurnal Pemikiran Syariah dan Hukum 
dan jenis hukuman yang ditimpakan ('uqübiyah). Sedangkan menyangkut keadaan pelaku(subjek/pertanggungjawaban pidana) umumnya menjadi satu bagian dari pembahasan jenis perbuatan pidana, walaupun bahasan subjek tidak dipisah secara tersendiri, tetapi tetap masuk menjadi bagian dari ruang lingkup yang dibahas dalam hukum pidana Islam, yakni menyangkut jenis perbuatan pidana dan jenis hukumannya. ${ }^{12}$

Dalam hukum Islam, pidana dibagi berdasarkan kepada: Pertama, berat dan ringannya hukuman. Kedua, Niat. Ketiga, Waktu. Keempat, Cara, Kelima, Objek. Keenam, tabiatnya.

Pertama, bila dilihat pada berat dan ringannya, hukum pidana Islam terbagi atas tiga bagian, yakni jarimah hu dūd, jarimah qishash dan di'at, serta jarimah ta'zir. Kedua, dari segi niat, terbagi menjadi dua, yakni jarimah sengaja (jará'im maqsudah dan tidak segaja (jará'im ghayr maqsūdah). Ketiga, dari segi waktu, juga terbagi dua, yakni: jarimah tertangkap basah, dan jarimah yang tidak tertangkap basah, jarimah tertangkap basah adalah jarimah di mana pelakunya tertangkap pada waktu melakukan perbuatan tersebut atau sesudah tetapi dalam masa yang dekat. Sedangkan jarimah tidak tertangkap basah adalah jarimah di mana pelaku tidak tertangkap pada wktu melakukan perbuatan tersebut, melainkan sesudahnya dengan lewatnya waktu yang tidak sedikit. Keempat, bila dilihat dari cara melakukannya, terbagi menjadi dua, yakni positif (jarimah ijäbiyyah) adalah jarimah yang terjadi karena melakukan perbuatan yang dilarang, dan negatif (jarimah salābiyyah) adalah jarimah yang terjadi karena meninggalkan perbuatan yang diperintahkan. Kelima, dilihat dari segi objeknya, terbagi pada; jarimah perseorangan (jarâ'im dzid al-'afrad) dan jarimah masyarakat (jarā'im dzid al-jamā'ah). Keenam, dari segi tabiatnya, terbagi menjadi jarimah biasa (jarimah 'adiyah) dan politik (jarimah siyāsiyah). ${ }^{13}$

Dalam penelitian yang dilakukan oleh guru besar sistem peradilan pidana dari Sam Houston State University, Texas Amerika Serikat, mencatat bahwa selama sepuluh tahun rata-rata angka kejahatan di Arab Saudi paling kecil dibanding negara-negara Muslim lain yang tidak menerapkan hukum pidana Islam. Satu sebabnya, menurut Prof. Souryal,

\footnotetext{
${ }^{12}$ Asep Saepudin Jahar , Hukum Keluarga, Pidana ..., 114-115.

${ }^{13}$ Ibid., 116-119.
} 
syariat Islam sangat berperan dalam membentuk satu masyarakat anti kejahatan (noncriminal society) dan masyarakat dengan kontrol sosial yang tinggi. ${ }^{14}$

Hukum pidana Islam pada dasarnya memenuhi syarat sebuah hukum pidana modern. Hukum ini juga mengenal asas-asas atau prinsipprinsip penting hukum pidana, baik yang sudah dikenal oleh hukum Barat maupun yang belum, seperti asas legalitas, asas tidak berlaku surut, asas tiada pidana jika da keraguan, asas kesamaan di hadapan hukum, asas praduga tidak bersalah, asas perlindungan HAM, asas keadilan, asas kebenaran materiil, asas kemanfaatan, asas pemaafan, asas individualisasi pemidanaan, dan sebagainya. Satu hal yang jelas, yakni hukum pidana Islam berbeda dengan hukum Barat yang tidak mengakui aspek agama. Hukum ini justru sangat erat hubungannya dengan agama sebagai jalan hidup manusia. ${ }^{15}$

\section{Hukum Pidana di Indonesia}

Hukum pidana yang berlaku di Indonesia sekarang ini ialah hukum pidana yang telah dikofisir, yaitu sebagian terbesar dari aturanaturannya telah disusun dalam satu kitab undang-undang (wetboek), yang dinamakan Kitab Undang-undang Pidana, menurut suatu sistem yang tertentu. Selain daripada bahwa hukum pidana kita telah dikodifisir maka bagian hukum ini juga telah diunifisir, yaitu berlaku bagi seluruh golongan-golongan rakyat, sehingga tidak ada dualisme lagi. ${ }^{16}$

Baik di dalam hukum Islam maupun hukum pidana, ternyata terdapat kesamaan-meskipun tidak serupa-tentang ruang lingkup dan pembagian hukum pidana. Yakni menyangkut subjek (pelaku kejahatan), objek (perbuatan yang dilarang), dan sanksi (hukuman yang akan diterapkan). Tentang subjek (pelaku kejahatan) bahasa-nya lebih banyak ditekankan kepada kondisi dan keadaan pelaku kejahatan yang bisa dijatuhi hukuman atau sering juga disebut pertanggungjawaban pidana. ${ }^{17}$

\footnotetext{
${ }^{14}$ Santoso, Membumikan Hukum Pidana..., 89.

${ }^{15}$ Ibid.

${ }^{16}$ Moeljatno, Asas-asas Hukum Pidana (Jakarta: Rineka Cipta, 2002), 16-17.

${ }^{17}$ Asep Saepudin Jahar , Hukum Keluarga, Pidana ..., 114.
} 
Hukum pidana di Indonesia yang menjadi acuan adalah Kitab Undang-undang Hukum Pidana atau disingkat KUHP sebagai hukum materiil-nya. Pada prinsipnya sistem aturan umum pemidanaan dalam KUHP (WvS) tidak hanya ditujukan pada orang yang melakukan tindak pidana, tetapi juga terhadap mereka yang melakukan perbuatan dalam bentuk percobaan, pemufakatan jahat, penyertaan, perbarengan (concurus), dan pengulangan (recidive). Hanya saja di dalam KUHP, pemufakatan jahat dan recidive tidak diatur dalam Aturan Umum Buku I, tetapi di dalam Aturan Khusus (Buku II atau Buku III). Terdapat tiga masalah pokok dalam hukum pidana yaitu tindak pidana, pertanggungjawaban pidana, serta pidana dan pemidanaan, masingmasing merupakan sub-sistem dan sekaligus pilar-pilar dari keseluruhan bangunan sistem pemidanaan. ${ }^{18}$

Di dalam KUHP diatur batas-batas berlakunya aturan pidana; dasar penghapus; pemberat dan peringgan pidana; penyertaan melakukan tindak pidana; serta gabungan tindak pidana, dan sebagainya. Pada intinya, tidak pidana dibedakan menjadi dua macam, yakni kejahatan dan pelanggaran. ${ }^{19}$

\section{Konsep Hukuman Mati}

Di Indonesia, hukum pidana mati adalah salah satu hukuman pokok yang tercantum dalam pasal $10 \mathrm{KUHP}$ dan tercantum pada pasal 43 dari Rancangan KUHP Nasional. Dalam pasal tersebut, hukuman mati ditetapkan dalam satu urutan pertama dalam jajaran hukuman pokok. Penetapan hukuman sebagai hukuman pokok dalam pasal 43 Rancangan KUHP Nasional tersebut memberi kesan bahwa para pemikir yang tergabung dalam BPHN tetap berpandangan bahwa hukum pidana mati masih dinilai urgen. Dalam RUU KUHP yang sekarang, hukum pidana mati juga dimasukkan dan menjadi kontroversi. ${ }^{20}$

Selain di Indonesia, negara lain seperti Malaysia, Singapore, dan

${ }^{18}$ Badan Pembinaan Hukum Nasional Kementerian Hukum dan Hak Asasi Manusia RI, "Draft Naskah Akademik Rancangan Undang-Undang Tentang Kitab Undang-Undang Hukum Pidana (KUHP)", 16. http://www.bpjn.go.id/data/documents/naskah_akademik_tentang_kuhp_ dengan_lampiran.pdf. (diakses tanggal 22 Oktober 2015).

${ }^{19}$ Santoso, Membumikan Hukum Pidana...,83.

${ }^{20}$ Sahid HM, Tinjauan Syari'ah Terhadap Hukum Pidana Mati..., 50. 
Arab Saudi juga memberlakukan hukum pidana mati. Hanya saja mekanisme hukuman yang diberikan kepada pelaku tindak pidana berbeda. Di Malaysia, hukum pidana mati dengan digantung lehernya. Tingkat pelanggaran yang diberikan kepada pelaku tindak pidana juga berbeda. Realitas ini membuktikan bahwa sebagian negara menganggap urgen terhadap hukum pidana mati. ${ }^{21}$

Dalam Islam hukuman Qishashini didasarkan pada ayat al-Qur'an dalam surah al-Baqarah: 1780-179: bahwa seseorang yang melakukan jarimah pembunuhan harus dijatuhi hukuman qishash, yaitu hukuman yang serupa, yakni hukuman mati. Hukuman qishash tersebut dilakukan bertujuan adalah agar tercipta persamaan keadilan antara yang kuat dengan yang lemah dan golongan yang banyak dengan yang sedikit. Dari ayat itu juga dipahami bahwa hukuman mati tersebut dapat tidak dilaksanakan apabila wali (keluarga) yang terbunuh itu memaafkan pihak yang melakukan pembunuhan. Dalam keadaan yang demikian bagi pembunuh diwajibkan memberikan ganti rugi (diyat) kepada keluarga yang terbunuh untuk ketentuan jumlahnya ditetapkan oleh hukum fiqih, inilah dasar hukum mengenai jarimah pembunuhan, tentunya semua itu dilaksanakan oleh putusan hakim. ${ }^{22}$

Dengan ungkapan lain, qishash ialah melakukan tindakan pembalasan yang sama. Kendatipun demikian, manakala yang membunuh mendapat kema'afan dari ahli waris yang terbunuh, yaitu dengan membayar diyat (ganti rugi) yang wajar. Pembayaran diyat diminta dengan baik, umpamanya dengan tidak mendesak yang membunuh, dan yang membunuh hendaklah membayarnya dengan baik, umpamanya tidak menangguh-nangguhkannya. ${ }^{23}$

Islam menentukan cara untuk melindungi masyarakat dari kejahatan pembunuhan, kemudian telah mempertimbangkan hal-hal yang akan terjadi dalam kelompok masyarakat. Untuk mengatasi hal-hal yang terjadi itu, maka ditetapkanlah hukum sebagai sanksinya. ${ }^{24}$

${ }^{21}$ Ibid., 50-51.

${ }^{22}$ M. Rizal, "Penerapan Hukum Pidana Mati Perspektif Hukum Islam Di Indonesia", Nurani Vol. 15 No.1 (2015), 105. http://jurnal.radenfatah.ac.id/index.php/Nurani/article/ download/277/234. (diakses tanggal 8 Desember 2015).

${ }^{23} \mathrm{Ibid}$.

${ }^{24}$ Ibid., 106.

Sangaji Jurnal Pemikiran Syariah dan Hukum 
Dalam hukum Islam, ada tiga bentuk pembunuhan. yaitu: Pertama, Pembunuhan disengaja yaitu seseorang dengan direncanakan menghilangkan nyawa orang lain. Terhadap jarimah semacam ini, maka pelaku pembunuhan wajib dibunuh pula. Apabila keluarga korban memaafkan maka hukuman tidak bisa dijatuhkan, maka kepada pembunuhnya dikenakan diyat. Kedua, pembunuhan Seperti disengaja yaitu seseorang dengan maksud bergurau melempar temannya dengan kerikil, tidak diduga bahwa perbuatannya itu akan mematikan orang lain (al-Jaziri, 1964:440). Terhadap jarimah ini tidak diwajibkan qishash tapi wajib membayar denda. Ketiga, Tidak disengaja membunuh, umpamanya seseorang menembak buruannya tetapi sasarannya kena kepada manusia (Al-Qasimi, 2, 1959: 401). Terhadap jarimah tersebut tidak wajib qishash tetapi membayar diyat kepada wali korban. ${ }^{25}$

Hukum Islam secara tegas menindak segala bentuk jarimah, siapapun pelakunya, tetapi di balik itu bahwa syari'at Islam tidak terlepas dari moralitasnya, yaitu selalu memperhatikan aspek lain di samping prosedur yang telah ditetapkan, seperti aspek moral, prikemanusiaan dankehidupan sosial masyarakat di wilayah kejadian jarimah. ${ }^{26}$

Adapun bentuk jarimah yang dapat dikenakan hukuman mati, adalah sebagai berikut: Pertama, pembunuhan disengaja. Kedua, Pezina Muhson (Ibn Rusyd, 2, 1960: 435). Ketiga, Muharib. Terhadap pelaku jarimah ini dikenakan empat hukuman yaitu hukuman mati biasa, hukuman mati disalib, dipotong tangan dan kaki secara bersilang dan diasingkan. Ketentuan ini didasarkan pada Firman Allah dalam AlQur'an (QS. 5 Al-Maidah: 33). Keempat, Murtad. Terhadap pelaku jarimah ini diancam hukuman mati sebagai hukuman pokok kemudian dirampas harta bendanya sebagai hukuman tambahan. Firman Allah SWT dalam surat al-Baqarah ayat $217 .{ }^{27}$

Persoalan korupsi, dari hasil riset yang dilakukan oleh berbagai lembaga, juga menunjukkan bahwa tingkat korupsi di Indonesia yang mayoritas penduduknya beragama Islam ini termasuk yang paling tinggi di dunia. Bahkan koran Singapura, The Straits Times, sekali waktu

\footnotetext{
25 Ibid.

26 Ibid.

27 Ibid.
} 
pernah menjuluki Indonesia sebagai the envelope country. ${ }^{28}$

Korupsi telah diposisikan sebagai kejahatan yang mengakar di tubuh bangsa Indonesia. Kondisi ini memaksa bukan hanya pada upaya pemberantasan tindak pidana korupsi melalui pengaturan kategori tindak pidana khusus, melainkan sampai pada tingkat upaya pemberian sanksi maksimal, berupa hukuman mati. Walaupun pencantuman hukuman mati dalam tidak pidana korupsi bersifat khusus. Namun di sisi lain, pemberian sanksi hukum mengalami perkembangan yang meletakkan pergeseran, khususnya pemberian sanksi hukuman mati. Hukuman mati diposisikan sebagai bentuk hukuman yang melanggar hak dasar kemanusiaan untuk hidup. Di samping itu, efek jera yang dilahirkan oleh hukuman mati tidak menunjukkan bukti signifikan dan berlaku efektif dibandingkan hukuman lainnya. ${ }^{29}$

\section{Perdebatan Eksistensi Hukum Pidana Islam Sebagai Bahan Materiil Dalam Kebijakan Hukum Pidana di Indonesia}

\section{Proses Legislasi Hukum Islam di Indonesia}

Proses legislasi hukum Islam bukan berarti mulus begitu saja, tetap saja ada faktor-faktor yang mempengaruhi dalam proses legislasi-nya, misalkan pengaruh penjajahan, serta pemikiran-pemikiran Liberal yang cukup membuat pusing bagi kalangan cendekiawan dan ulama tentang konsep-konsep hukum Islam, namun bukan berarti kritikan tersebut membuat pemberlakuan hukum Islam menjadi terhenti, akan tetapi menjadi bahan pertimbangan guna menyesuaikan dengan keadaan masyarakat Islam terkhusus di Indonesia.

Keberhasilan proses legislasi hukum Islam dengan lahirnya Undangundang No. 1 tahun 1974 tentang perkawinan, Undang-undang No. 7 Tahun 1989 tentang Pengadilan Agama, Undang-undang tentang Ibadah Haji, Zakat, Kompilasi Hukum Islam, dan Wakaf, juga mengalami kendala serta perdebatan yang serius dalam hal penetapannya, namun

${ }^{28}$ Amirullah, "Tindak Pidana Korupsi dan Sanksi Pidana Mati Perspektif Keadilan Hukum", Al- Daulah Vo. 3 No. 2. (2013), 325. http://aldaulah.uinsby.ac.id/index.php/aldaulah/ article/download/98/85. (diakses tanggal 8 Desember 2015).

${ }^{29}$ Ibid., 327-328.

Sangaji Jurnal Pemikiran Syariah dan Hukum 
hukum negara masih mengakomodir terkait masalah ke-perdata-an, sedangkan hukum pidana masih dengan konsep hukum Belanda yakni KUHP.

Selain itu adanya Undang-undang otonomi khusus yang berlaku di Aceh menjadi langkah awal dalam praktek dan cerminan akan konsep hukum negara mengakomodir hukum Islam baik itu keperdataan dan juga pidana. Ini menjadi langkah awal bagi Negara dalam hal ini pemerintahan Aceh menjadikan hukum Islam sebagai konsep hukum dalam peraturan daerahnya.

Persoalan ini tidak luput dari pro-kontra akan kekhususannya, Sekalipun telah diberi kewenangan dan otonomi luas di bidang hukum Islam pasca pemberlakuan Undang-undang Pemerintahan Aceh (UUPA) No. 11/2006, syariat Islam di Aceh dalam kurun enam tahun penerapan UUPA masih menampakkan gejala anomali. Pada satu sisi, wewenang dan otonomi bagi Aceh dalam menyusun qanun syariat (peraturan setingkat Perda/Peraturan Daerah) diperluas dari sebelumnya hanya mengurusi wilayah ibadah, ahwal syakhsiyah dan muamalah, merambah ke bidang hukum jinayah (pidana). Tak hanya itu, muatan sanksi hukuman bagi qanun jinayat juga dikecualikan dari ketentuan umum sanksi ('uqubat) yang dapat dimuat dalam qanun asalkan sesuai dengan yang diatur dalam peraturan perundangundangan lain. Namun pada sisi lain, kewenangan dan jurisdiksi terbatas ini menghadapi persoalan besar manakala proses inkorporasi hukum Islam dalam qanun syariat Aceh juga harus dibangun dalam bingkai (frame) dan lingkup sistem hukum nasional, sehingga sedikit banyak qanun syariat itu nantinya harus mengalami berbagai "penyesuaian" dengan realitas hukum yang berlaku di Indonesia.

\section{Diskursus Hukum Pidana Islam Sebagai Sumber Hukum di Indonesia}

Diskursus formalisasi syariat Islam yang cukup gencar tersebut telah menimbulkan pro dan kontra. Salah satu pandangan berusaha mementahkan ajakan formalisasi syariat Islam. Penolakan formalisasi syariah ini diungkapkan dengan berbagai argumentasi dan dalil. Misalnya, ada yang mengatakan bahwa Indonesia adalah masyarakat plural, tidak hanya Muslim, maka formalisasi syariat Islam yang berlaku 
umum tidak dapat diterima. Bahkan ada yang mempertanyakan, kalau mau memformalisasikan syariat Islam, syariat Islam yang mana? Bukankah varian pemahaman umat Islam tentang syariat Islam sifat beragam tidak tunggal? Ada pula yang menyatakan bahwa formalisasi syariat Islam berarti intervensi negara terhadap kehidupan beragama yang seharusnya bersifat privat dan individual. Ada pula yang menolak formalisasi syariat Islam karena syariat Islam tidak sesuai dengan modernitas dan kehidupan publik, misalnya Hukum Internasional, HakHak Asasi Manusia, Demokrasi, dan sebagainya. ${ }^{30}$

Sedikitnya, ada tiga arus besar yang mengemuka dalam menyikapi formalisasi syariat Islam. Pertama, arus formalisasi syariat. Kelompok ini menghendaki agar syariat Islam dijadikan landasan riil berbangsa dan bernegara. Pencantuman kembali Piagam Jakarta dalam UUD 1945 menjadi salah satu target utamanya. Kedua, arus deformalisasi syariat. Kelompok ini memilih pemaknaan syariat secara substantif. Pemaknaan syariat tidak serta-merta dihegemoni negara, karena wataknya yang represif. Syariat secara individu sudah diterapkan, sehingga formalisasi dalam UUD 1954 tidak mempunyai alasan kuat dalam ranah politik. Ketiga, arus moderat Kelompok ini dikesankan mengambil jalan tengah: menolak sekularisasi dan Islamisasi, karena budaya masyarakat Muslim Indonesia mempunyai kekhasan tersendiri. Sekularisasi dan Islamisasi merupakan barang impor yang tidak cocok dengan identitas masyarakat, sehingga keduanya berpotensi untuk melakukan indoktrinsasi dan ideologisasi. ${ }^{31}$

Kendala dalam penegakan hukum pidana Islam masih banyak, yakni: ${ }^{32}$

1. Kendala kultural atau sosiologis, yakni adanya umat Islam yang masih belum bisa menerima;

2. Kendala fikrah (pemikiran), yaitu banyaknya pandangan negatif terhadap hukum pidana Islam dan kurang yakin dengan efektivitasnya;

3. Kendala filosofis berupa tuduhan bahwa hukum ini tidak adil bahkan kejam dan ketinggalan zaman serta bertentangan dengan

${ }^{30}$ Yusdani, "Formalisasi Syariat Islam dan Hak Asasi Manusia Di Indonesia," Al-Mawarid Edisi XVI, (2006), 193. http://journal.uii.ac.id/index.php/JHI/article/download/244/239. (diakses tanggal 20 Oktober 2015).

${ }^{31}$ Ibid.

${ }^{32}$ Santoso, Membumikan Hukum Pidana..., 86. 
cita-cita hukum nasional;

4. Kendala yuridis yang tercermin dari belum adanya ketentuan hukum pidana yang bersumber dari syariat Islam;

5. Kendala konsolidasi, yakni belum bertemunya para pendukung pemberlakuan syariat Islam (dari berbagai kalangan) yang masih saling menonjolkan dalil (argumen) dan metode penerapannya masing-masing;

6. Kendala akademis, terlihat dari belum meluasnya pengajaran hukum pidana Islam di sekolah atau kampus-kampus;

7. Kendala perumusan yang terlihat dari belum adanya upaya yang sistematis untuk merumuskan hukum pidana yang sesuai syariat Islam sebagai persiapan mengganti hukum pidana Barat;

8. Kendala struktural yang terlihat dari belum adanya struktur hukum yang dapat mendukung penerapan syariat Islam;

9. Kendala politis, terlihat dari tidak cukupnya kekuatan politik untuk menggolkan penegakan syariat Islam melalui proses-proses politik. Ada dua kontroversi besar yang muncul pada akhir 2009 berkaitan dengan penerapan syariat Islam di Aceh. Pertama, pengesahan Qanun Jinayat dan Qanun Hukum Acara Jinayat oleh Dewan Perwakilan Rakyat Aceh (DPRA). Qanun ini menjadi kontroversi karena di dalamnya dimuat hukum rajam bagi orang yang melakukan zina. Rajam merupakan kata yang ditakuti oleh banyak orang dan dianggap melanggar hak asasi manusia (HAM). Kontroversi kedua, keputusan bupati Aceh Barat yang mengeluarkan aturan larangan menggunakan celana panjang pada perempuan di daerahnya. Celana panjang dianggap tidak mewakili pakaian yang menutup aurat secara Islami. Bupati menganggap satusatunya pakaian yang mewakili cara Islam adalah rok panjang pada perempuan. Ketentuan ini juga memunculkan berbagai polemik di kalangan masyarakat dan pemerintah. Berbeda dari kasus pertama yang umumnya ditentang oleh organisasi sosial dan kelompok Islam liberal, keputusan Bupati Aceh Barat ini juga ditentang oleh sejumlah ulama Aceh sendiri, termasuk ketua Majelis Permusyawaratan Ulama (MPU) Aceh. ${ }^{33}$

33 Sehat Ihsan Shadiqin, "Islam dalam Masyarakat Kosmopolit: Relevankah Syariat Islam Aceh untuk Masyarakat Modern?" Kontekstualita, Vol. 25, No. 1, (2010), 23-24. http:// download.portalgaruda.org/article.php?article $=252354 \&$ val $=6802 \&$ title $=I$ slam $\% 20$ dalam $\% 20$ 
Kedua kontroversi di atas bermula dari keistemewaan yang diberikan oleh pemerintah pusat kepada Aceh untuk melaksanakan syariat Islam melalui UU No. 18 Tahun 2001. Keistemewaan ini memungkinkan pemerintah Aceh mengeluarkan peraturan daerah (qanun) yang berisi implementasi hukum Islam sebagai hukum positif yang akan diterapkan dalam kehidupan masyarakat. Di level provinsi, sejauh ini pemerintah Aceh telah mengeluarkan tujuh qanun yang berkaitan dengan implementasi syariat Islam. Qanun-qanun tersebut lebih banyak yang berhubungan dengan masalah privat individu dan hanya sedikit menyentuh masalah-masalah publik. Akibatnya, banyak pihak yang menganggap pemberlakuan qanun syariat Islam di Aceh cenderung mengatur hal-hal yang tidak terlalu signifikan.

Hal ini diperparah lagi dengan kenyataan, yang banyak menjadi tersangka dalam penerapan qanun tersebut adalah perempuan dan masyarakat sipil yang tidak memiliki akses politik dan kekuasaan. Oleh sebab itu, semua aturan yang ada di Aceh saat ini mendapatkan respons dari berbagai lembaga kemanusiaan dunia. Qanun dan aturan yang dikeluarkan menyangkut pakaian, hubungan laki-laki dan perempuan, perjudian, dan lainnya yang ada di Aceh, juga tidak terlepas dari tanggapan pihak luar Aceh yang mengatasnamakan kehidupan yang egaliter dan menjunjung tinggi hak asasi manusia (HAM) yang harus ditegakkan di semua lini. Kelompok ini terdiri atas aktivis HAM, gender dan feminis, kelompok pemikir Islam liberal, serta berbagai kelompok lainnya. ${ }^{34}$

Rancangan Undang-undang Kitab Undang-undang Hukum Pidana, yang dari sejak dulu masih belum selesai sedangkan problem hukum sudah mulai kompleks, adanya pasal-pasal yang di dalamnya memberikan efek jera, dimana salah satu sumbangsih dalam hukum Islam, yakni kelemahan dalam KUHP adalah terkait masalah perzinahan, hal ini menjadi prioritas pertama akan kuatnya pengaruh Islam dalam kesusilaan, misalkan selain perzinahan, antara lain terkait pasal kumpul kebo, homoseks, perkawinan sejenis, larangan seks di luar nikah dan

Masyarakat\%20Kosmopolit:\%20Relevankah\%20Syariat\%20Islam\%20Aceh\%20untuk\%20 Masyarakat\%20Modern? (diakses tanggal 22 Oktober 2015).

${ }^{34}$ Sehat Ihsan Shadiqin , "Islam dalam Masyarakat Kosmopolit..., 25.

Sangaji Jurnal Pemikiran Syariah dan Hukum 
pornografi. Tetapi dari segi hukuman, sama sekali tidak mengacu kepada hukum pidana Islam.

\section{Kesimpulan}

Dari pemaparan tentang perkembangan hukum Islam di atas dapat kita pahami dan simpulkan bahwa:

Pertama, proses pembentukan hukum pidana yang berlaku di Indonesia masih terpaku dengan Kitab Undang-undang Hukum Pidana (KUHP) yang merupakan hasil dari hukum pada saat kolonial, yang dianggap masih nyaman dan tidak merasa dirugikan oleh sebagian pihak, persoalan perbedaan pendapat dan kehati-hatian menjadi kendala dalam proses penetapan hukum pidana dalam penerapannya di Indonesia, akan tetapi menjadi bahan penting dalam pertimbanganpertimbangan perumusan Rancangan Undang-undang Kitab Undangundang Hukum Pidana (RUU KUHP). Selain dari itu, masih adanya isuisu yang beranggapan bahwa hukum Islam bersifat keras dan melanggar HAM menjadi persoalan penting guna memberikan pemahaman bahwa konsep Hukum Islam tidaklah begitu. Selain itu melihat hukum Islam yang sudah mengakar di masyarakat Indonesia tentu menjadi poin penting dalam mempertimbangkan hukum Islam sebagai sumber hukum dalam pidana di Indonesia.

Kedua, Melihat dengan masih maraknya tindak kejahatan yang terjadi membuat masyarakat beranggapan bahwa, hukum pidana memberikan sanksi yang tidak sepadan dengan apa diberikan kepada para pelaku tindak pidana, selama ini tidak membuat jera pada mereka untuk mengulanginya. Karena itu, sanksi yang tegas seperti yang ada dalam Hukum Pidana Islam serta prinsipnya nampaknya merupakan alternatif yang perlu dipertimbangkan sebagai sumber hukum agar dapat mengatasi permasalahan tindak pidana di Indonesia. Selain itu masih adanya persoalan sosial yang berkaitan dengan ketertiban dalam hal ini persoalan kesusilaan seperti perzinaan yang dilakukan antara wanita dan lelaki yang masih lajang dan kumpul kebo, yang tidak tercakup dalam pidana sekarang, akan tetapi meresahkan masyarakat, maka harusnya perlu untuk dibuat, maka tidak heran jika ada aturan hukum yang dibuat oleh masyarakat secara adat dalam memberikan 
punishment (hukuman) guna ketertiban yang tidak mereka dapatkan di hukum bisa mereka terapkan dalam lingkungannya.

Selain itu, adanya kesamaan hasil hukum yang berupa putusan pengadilan yang dianggap sama dan sesuai dengan ketentuan HPI, seperti hukuman mati dan langkah awal pemberlakuan sanksi pidana cambuk seperti yang diberlakukan di Nanggro Aceh Darussalam (NAD), hal-hal seperti itulah yang perlu dipertimbangkan guna adanya efek jera dan ketaatan hukum, meski dalam hal ini tergantung pada subjek atau pelaku atas ketentuan hukum yang berlaku. Persoalan perzinahan juga cukup membuat resah, maka perlu adanya unsur Hukum Pidana Islam dalam penerapannya terlebih di Indonesia termasuk mayoritas beragama Islam.

\section{Daftar Pustaka}

Amirullah, "Tindak Pidana Korupsi dan Sanksi Pidana Mati Perspektif Keadilan Hukum", Al- Daulah Vo. 3 No. 2. (2013), 325. http://aldaulah.uinsby.ac.id/index.php/aldaulah/article/ download/98/85. (diakses tanggal 8 Desember 2015).

Badan Pembinaan Hukum Nasional Kementerian Hukum dan Hak Asasi Manusia RI, "Draft Naskah Akademik Rancangan Undang-Undang Tentang Kitab Undang-Undang Hukum Pidana (KUHP)", 16. http:// www.bpjn.go.id/data/documents/naskah_akademik_tentang_ kuhp_dengan_lampiran.pdf. (diakses tanggal 22 Oktober 2015).

Djubaedah, Neng. Perzinaan Dalam Peraturan Perundang-undangan di Indonesia Ditinjau Dari Hukum Islam. Jakarta: Kencana, 2010.

Faisal , "Menimbang Wacana Formalisasi Hukum Pidana Islam di Indonesia" Ahkam: Vol. XII No.1 (2012), 44. http://download.portalgaruda. org/article.php? article $=176035 \&$ val $=328 \&$ title $=$ Menimbang $\% 20$ Wacana\%20Formalisasi\%20Hukum\%20Pidana\%20Islam\%20 di\%20Indonesia. (diakses tanggal 23 Oktober 2015).

HM, Sahid. “Tinjauan Syari'ah Terhadap Hukum Pidana Mati”, AlDaulah: Jurnal Hukum dan Perundangan Islam Vol. 2 No. 1 (2012), 49-50. http://aldaulah.uinsby.ac.id/index.php/aldaulah/ article/download/116/103. (diakses tanggal 8 Desember 2015).

Sangaji Jurnal Pemikiran Syariah dan Hukum 
Jahar, Asep Saepudin. dan Euis Nurlaelawati-Jaenal Aripin, Hukum Keluarga, Pidana \& Bisnis Kajian Perudang-undangan Indonesia, Fikih dan Hukum Internasional. Jakarta: Kencana, 2013.

Jazuni, Legislasi Hukum Islam di Indonesia. Bandung: Citra Aditya Bakti, 2005.

Marzuki, "Prospek Pemberlakuan Hukum Pidana Islam Di Indonesia" Universitas Yogyakarta, 4.http://staff.uny.ac.id/sites/default/files/ penelitian/Dr.\%20Marzuki,\%20M.Ag./Dr.\%20Marzuki,\%20M. Ag_.\%20Prospek\%20Pemberlakuan\%20Hukum\%20Pidana\%20 Islam\%20di\%20Indonesia.pdf. (diakses tanggal 23 Oktober 2015). Moeljatno, Asas-asas Hukum Pidana. Jakarta: Rineka Cipta, 2002.

Rizal, M. "Penerapan Hukum Pidana Mati Perspektif Hukum Islam Di Indonesia", Nurani Vol. 15 No.1 (2015), 105. http://jurnal. radenfatah.ac.id/index.php/Nurani/article/download/277/234. (diakses tanggal 8 Desember 2015).

Santoso, Topo. Membumikan Hukum Pidana Islam: Penegakan Syariat dalam Wacana dan Agenda. Jakarta: Gema Insani Press, 2003.

Shadiqin, Sehat Ihsan. "Islam dalam Masyarakat Kosmopolit: Relevankah Syariat Islam Aceh untuk Masyarakat Modern?" Kontekstualita, Vol. 25, No. 1, (2010), 23-24. http://download.portalgaruda.org/ article.php? article $=252354 \&$ val $=6802 \&$ title $=$ Islam $\% 20$ dalam $\% 20$ Masyarakat\%20Kosmopolit:\%20Relevankah\%20Syariat\%20 Islam\%20Aceh\%20untuk\%20Masyarakat\%20Modern? (diakses tanggal 22 Oktober 2015).

Yusdani, "Formalisasi Syariat Islam dan Hak Asasi Manusia Di Indonesia," Al-Mawarid Edisi XVI, (2006), 193. http://journal.uii. ac.id/index.php/JHI/article/download/244/239. (diakses tanggal 20 Oktober 2015). 